\title{
PEMFIGUS VULGARIS DISERTAI INFEKSI METHICILLIN RESISTANT STAPHYLOCOCCUS AUREUS: SEBUAH LAPORAN KASUS
}

\author{
Hasri Dewi Made, Wardhana Made, Sanjiwani Prima \\ Bagian/SMF Ilmu Kesehatan Kulit dan Kelamin \\ FK Universitas Udayana/RSUP Sanglah, Denpasar
}

\begin{abstract}
ABSTRAK
Pemfigus termasuk ke dalam kelompok penyakit autoimun, yang ditandai oleh bula mukokutaneus yang menyerang keratinosit antigen sebagai target dari autoantibodi, yang menyebabkan terjadinya akantolitik dan pembentukan bula. Tanpa penanganan yang tepat kondisi ini dapat menjadi fatal karena hilangnya fungsi barier epidermis, menyebabkan kehilangan cairan dan terjadinya infeksi sekunder. Seorang pasien laki-laki usia 58 tahun, dengan keluhan utama luka pada seluruh tubuh dan berbau tidak sedap, terdapat riwayat sariawan 2 bulan sebelumnya. Pada pemeriksaan dermatologi, di seluruh tubuh didapatkan makula hiperpigmentasi dan erosi multipel,ditutupi krusta coklat kehitaman. Di sakrum, didapatkan ulkus soliter, dasar kotor, ditutupi dengan jaringan nekrotik. Pemeriksaan kultur dasar luka didapatkan Providentia stuartii, dari hasil subkultur terisolasi Staphylococcus aureus yang merupakan kuman methicillin resistant staphylococcus aureus (MRSA). Pada pemeriksaan histopatologi didapatkan gambaran akantolitik yang menyisakan sel-sel basal epidermis kemungkinan bula suprabasal (mengarah pada gambaran pemfigus vulgaris). Diagnosis pada kasus ini pemfigus vulgaris yang disertai dengan infeksi MRSA. Terapi yang diberikan antibiotik sistemik, steroid, perawatan luka dan terapi suportif lainnya.
\end{abstract}

Kata kunci: MRSA, pemfigus vulgaris, steroid

\section{PEMPHIGUS VULGARIS ACCOMPANIED WITH METHICILLIN RESISTANT STAPHYLOCOCCUS AUREUS (MRSA) INFECTION: A CASE REPORT}

\begin{abstract}
Pemphigus refers to a group of autoimmune mucocutaneous blistering diseases, in which the keratinocyte antigens are the target of the autoantibodies, leading to acantholysis and blister formation. Without proper treatment, this condition can be fatal because of the loss of the epidermal barrier function, leading to loss of body fluids and secondary bacterial infection. A male patient 58 years old, with the chief complaint of arose wound on the whole body and bad smell, there is a history of mouth two months earlier. Dermatology examination, the location of the whole body is hyperpigmented macules and multiple erosions, covered in blackish-brown crusts. In the sacrum, there was a solitary ulcer, with dirty base, flat edges, pus, and covered with necrotic tissue. Wound culture result was Providentia stuartii, with the isolated subculture of Staphylococcus aureus, which is a bacterium of Methicillin-Resistant Staphylococcus Aureus (MRSA). Histopathological examination showed acantholytic process leaving the basal epidermal cells, possibly suprabasal bullae (referring to the description of pemphigus vulgaris). This case was diagnosed as pemphigus vulgaris accompanied by MRSA infection. Therapy given were systemic antibiotics, steroids, wound care, and other supportive therapies.
\end{abstract}

Key words: MRSA, pemphigus vulgaris, steroid

\section{Korespondensi:}

J1. Diponegoro No.1 Denpasar Bali, 80114

Telp: 0361-257517

Email: hasrimade@gmail.com 


\section{PENDAHULUAN}

Pemfigus vulgaris (PV) adalah penyakit bula intraepidermal kronik yang berpotensi menyebabkan bula dan erosi yang luas. ${ }^{1,2}$ Manifestasi klinis PV pada awalnya berupa bula di atas kulit normal yang selanjutnya berkembang menjadi bula dengan dasar eritematosa, kemudian pecah, sehingga timbul erosi yang biasanya disertai krusta dan rasa nyeri. Etiologi PV tidak diketahui, namun diperkirakan timbul sebagai hasil interaksi antara faktor genetik pejamu dan faktor pencetus yang berasal dari lingkungan misalnya obat-obatan, diet, sinar ultraviolet, virus, dan lainnya. ${ }^{3}$ Distribusi penyakit ini di seluruh dunia mengenai $0,1-$ 0,5 pasien per 100.000 populasi pertahun. Kasus PV di RSUP Sanglah Denpasar tercatat 11 kasus pada tahun 2014-2016. ${ }^{1,4}$ Pemfigus vulgaris dapat terjadi pada semua umur, namun sering mengenai usia pertengahan. ${ }^{1}$

Infeksi merupakan komplikasi yang sering terjadi pada pasien PV, akibat kerusakan sawar epidermis pada lesi pemfigus. Selain itu, perawatan di rumah sakit serta penggunaan obat imunosupresif menjadi faktor predisposisi terjadinya infeksi pada PV. Pada beberapa penelitian telah dilaporkan infeksi bakteri pada pasien PV. Zeinab dkk. ${ }^{5}$ melaporkan dari 196 pasien PV sebanyak 53,7\% mengalami infeksi jaringan lunak dan infeksi kulit yang disebabkan oleh Staphylococcus aureus dan 53,6\% adalah methicillin-resistant staphylococcus aureus (MRSA). ${ }^{5}$ Tim Pencegahan dan Pengendalian Infeksi (PPI) RSUP Sanglah pada tahun 2016 melaporkan kejadian infeksi MRSA sebanyak 23 kasus, dan pada periode Januari hingga Juni 2017 sebanyak 19 kasus. $^{6}$

\section{KASUS}

Seorang laki-laki berumur 58 tahun datang diantar oleh keluarganya ke IGD RSUP Sanglah dengan keluhan utama luka di seluruh tubuh dan berbau tidak sedap hingga dirasakan mengganggu orang di sekitarnya. Penyakit ini dikeluhkan sejak satu bulan yang lalu, berupa gelembung berisi cairan jernih dan mudah pecah menjadi luka pada badan, punggung, dan kedua lengan disertai nyeri. Gelembung dan luka bertambah banyak dan pasien mengeluh demam hilang timbul. Pasien juga mengeluhkan ada sariawan di mulut yang timbul sejak 2 bulan yang lalu. Selama sakit, pasien tidak pernah dimandikan dan alas tempat tidur juga tidak pernah diganti. Pasien merasa lemas hanya berbaring di tempat tidur. Pasien juga mengeluh ada luka di pinggang bagian bawah. Pasien diberikan ramuan rempah-rempah yang didapatkan dari dukun, namun tidak dibawa berobat ke dokter. Riwayat penyakit sistemik ataupun riwayat alergi obat atau makanan disangkal. Keluhan serupa pernah dialami oleh pasien 1 tahun yang lalu, berupa gelembung yang berisi cairan jernih dan mudah pecah pada badan dan kedua lengan namun tidak sebanyak sekarang. Pasien saat ini berobat ke dokter spesialis kulit dan kelamin, lesi membaik, tetapi tidak rutin kontrol.

Pada pemeriksaan fisis, didapatkan kesadaran baik, namun keadaan umum pasien lemah. Tekanan darah 120/80 mmHg, frekuensi pernapasan $22 \mathrm{kali} / \mathrm{menit}$, denyut nadi $120 \mathrm{kali} / \mathrm{menit}$, suhu aksila $38,5^{\circ} \mathrm{C}$, dan visual analog scale (VAS) 2. Pemeriksaan dermatologis pada sakrum, didapatkan ulkus soliter, bentuk bulat, dinding landai, ukuran $3 \mathrm{~cm} \times 2,5 \mathrm{~cm} \times 1,5 \mathrm{~cm}$, dasar kotor, tepi rata, terdapat pus, ditutupi dengan jaringan nekrotik (Gambar 1). Di seluruh tubuh didapatkan erosi multipel, bentuk geografika, ukuran $0,5 \times 1 \mathrm{~cm}$ hingga $1 \times 2 \mathrm{~cm}$, serta makula hiperpigmentasi, yang tersebar, beberapa ditutupi krusta coklat kehitaman, dan terdapat bekas rempah-rempah. Pada pewarnaan Gram dari lesi erosi didapatkan leukosit 10-15/lpb, bakteri kokus Gram positif, pada lesi ulkus didapatkan leukosit 15-20/lpb dan bakteri kokus Gram positif. Pada pemeriksaan histopatologi tampak sisa selsel di daerah aneksa kemungkinan terdapat bula suprabasal, sisa adneksa kulit menunjukkan akantolitik. Tampak papila dermis dengan pemanjangan rete ridges, yang mengalami akantolisis,tampak pula sebaran padat sel radang perivaskuler dan intertisial, terdiri atas leukosit polimorfonuklear, sel plasma dan limfosit,tidak tampak eosinofil pada sediaan ini. Pemeriksaan histopatologi tersebut mengarah pada gambaran PV (Gambar 2).

Hasil pemeriksaan kultur bakteri dapat terisolasi Providentia stuartii dari lesi erosi dan ulkus. Akan tetapi, dari hasil subkultur tanggal 26 Oktober 2016 didapatkan terisolasi Staphylococcus aureus yang merupakan kuman MRSA. Disarankan pemberian antibiotika linezolid, lakukan contact precaution, dan pasien dianjurkan untuk dimandikan dengan klorheksidin 2\%. Pemeriksaan darah lengkap menunjukkan leukositosis $\left(13,67 \times 10^{3} \mu \mathrm{L}\right)$ dan neutrofilia $\left(11,32 \times 10^{3} / \mu \mathrm{L}\right)$; penurunan hemoglobin $(7,51 \mathrm{~g} / \mathrm{dL})$ dan hematokrit $(38,02 \%)$, serta hipoalbuminemia $(1,59 \mathrm{~g} / \mathrm{dL})$.

Diagnosis banding pada pasien adalah pemfigus vulgaris, pemfigoid bulosa, pemfigus foliaceus, epidermolisis bulosa akuisita, dermatitis kontak iritan. Diagnosis kerja yang ditetapkan adalah pemfigus vulgaris disertai infeksi MRSA, ulkus dekubitus derajat 4, dermatitis kontak iritan, hipoalbuminemia dan anemia sedang. Pasien dirawat inap dan rawat bersama dengan bagian penyakit dalam dan bedah plastik. Penatalaksanaan cairan intravena berupa kombinasi $\mathrm{NaCl} 0,9 \%$, dekstrosa 5\%, dan Aminofusin. Pemberian antibiotik sistemik awalnya cefazoline 1 gram setiap 8 jam intravena, setelah ada hasil kultur dilanjutkan linezolid $600 \mathrm{mg}$ intravena setiap 12 jam selama 14 hari. Sebagai terapi PV, pasien mendapat metilprednisolon 125 mg intravena setiap 24 jam yang kemudian dosisnya diturunkan bertahap sesuai dengan kondisi klinis pasien. Pada hari ke-22 pasien mendapatkan dosis metilprednisolon $64 \mathrm{mg}$ peroral dibagi 2 dosis, parasetamol 1000 mg intravena setiap 8 jam jika demam, dan ranitidin 150 mg peroral setiap 12 jam. 

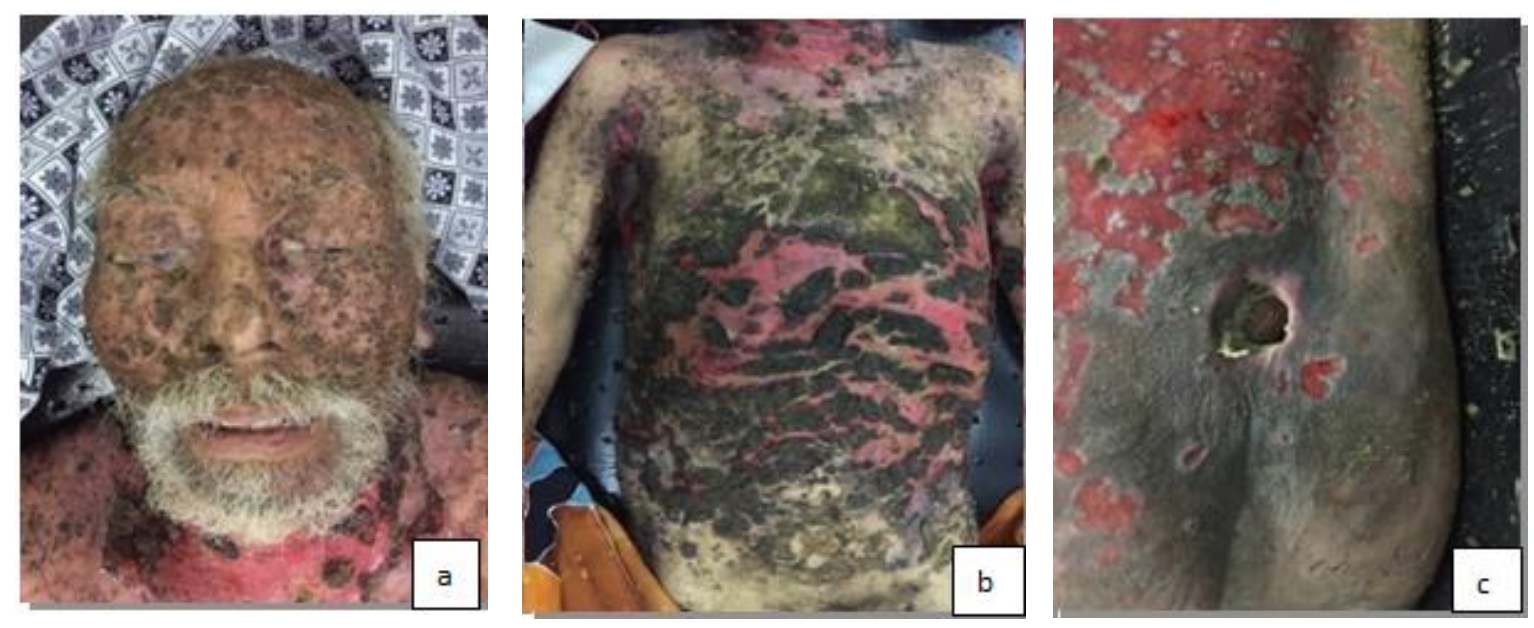

Gambar 1. Regio facialis (1a) regio thorakoabdominal anterior (1b) didapatkan makula hiperpigmentasi multipel, erosi multipel, beberapa ditutupi krusta coklat kehitaman dan terdapat bekas rempah-rempah dan regio sakrum (1c) ulkus soliter, bentuk bulat, dinding landai, dasar kotor, tepi rata, terdapat pus, ditutupi dengan jaringan nekrotik.
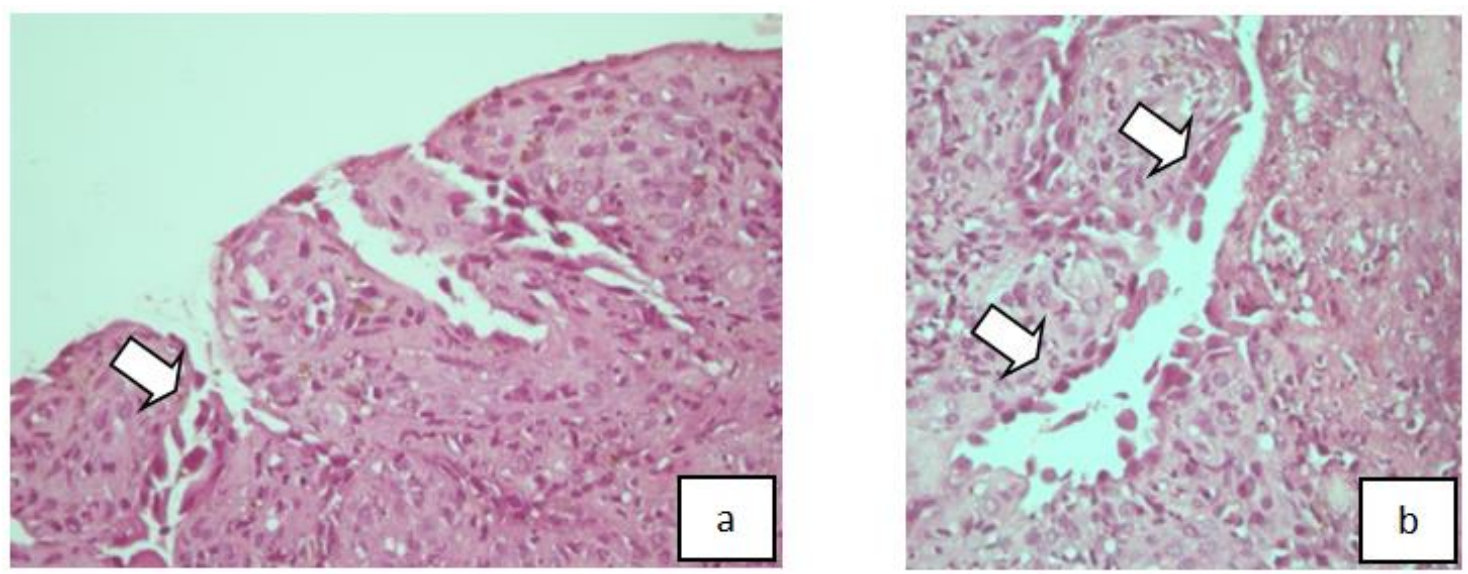

Gambar 2. Hasil pemeriksaan histopatologi dari spesimen.

Gambar 2a. Didapatkan tampak sisa sel-sel di daerah aneksa kemungkinan terdapat bula suprabasal. Gambar 2b. Sisa adneksa kulit menunjukkan akantolitik.

Untuk perawatan kulit, pasien awalnya dimandikan dengan kalium permanganas 1:10.000 setiap 12 jam. Setelah terdeteksi MRSA, pasien dimandikan dengan klorheksidin $2 \%$ setiap 12 jam, serta kompres dengan $\mathrm{NaCl}$ 0,9\% setiap 6 jam selama 15 menit pada lesi erosi dan ulkus di punggung. Untuk ulkus dekubitus direncana- kan debridement, namun ditunda karena kondisi pasien belum optimal, sehingga diterapi dengan tule antibiotik yang diganti setiap 24 jam. Pasien juga diberikan transfusi albumin dan packed-red cells (PRC), monitoring tanda vital dan keluhan. Perbaikan klinis tercapai dan pasien dipulangkan setelah 22 hari (Gambar 3). 

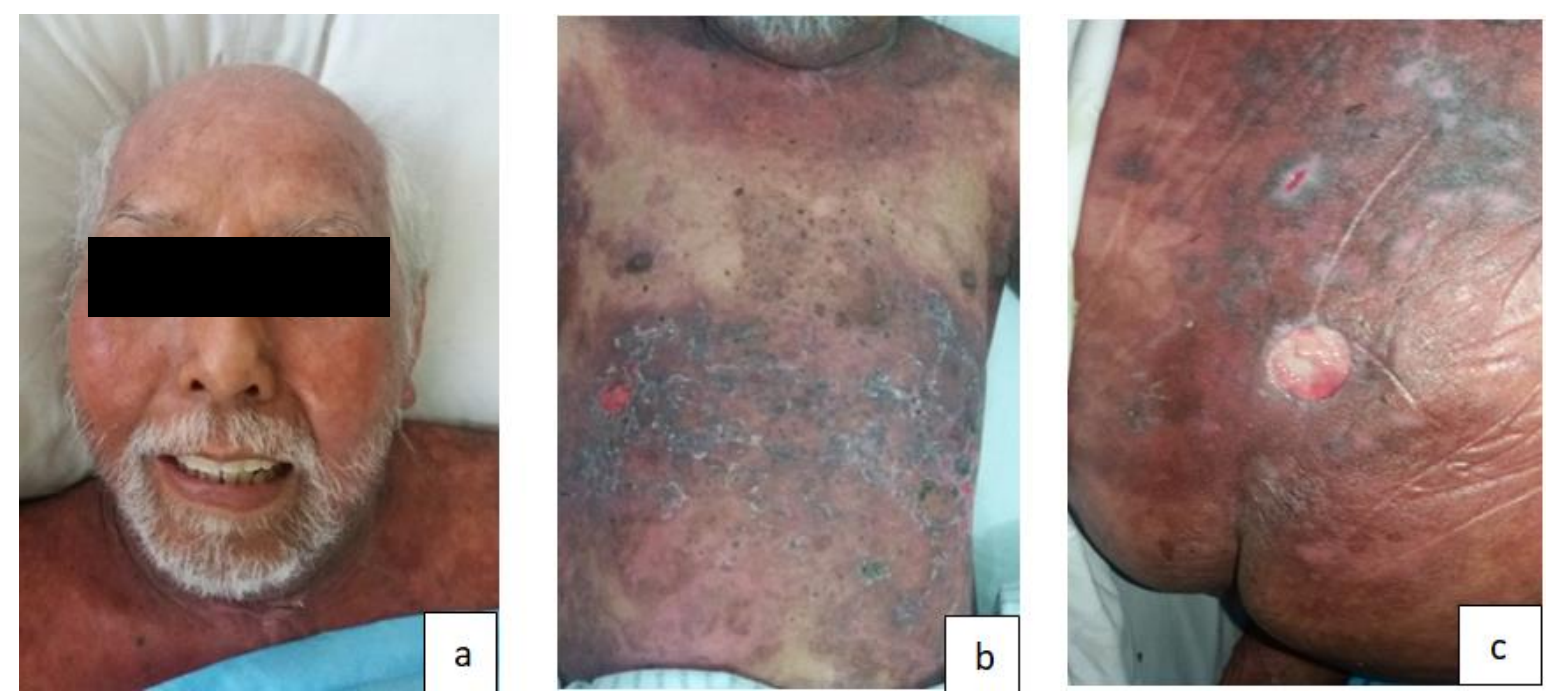

Gambar 3. Perbaikan setelah terapi pada wajah (3a), regio thorakoabdominal (3b) tampak lesi berupa makula eritema dan makula hiperpigmentasi, serta masih terdapat krusta coklat kehitaman yang menipis, lesi ulkus mengalami perbaikan (3c).

\section{DISKUSI}

Pemfigus vulgaris (PV) terutama terjadi pada orang dewasa dengan awitan antara usia 40-60 tahun, namun bisa terjadi pada anak-anak ataupun usia lanjut. ${ }^{1}$ PV dapat terjadi pada seluruh kelompok ras dengan prevalensi perempuan lebih tinggi dibandingkan dengan laki-laki sebesar 1,4:1. ${ }^{7,8}$ Pada kasus ini pasien adalah seorang laki-laki berusia 58 tahun. Patogenesis PV diperantarai oleh autoantibodi (autoAbs) yang secara langsung melawan desmoglein 3 (Dsg 3) yang terletak di permukaan sel keratinosit. Mekanisme pencetus yang mengawali respons imun belum diketahui. ${ }^{9,10}$ Desmoglein 3 bekerja sebagai lem yang berfungsi melekatkan sel epidermis yang saling berdekatan melalui satu titik perlekatan yang disebut dengan desmosom. Ketika antibodi menyerang Dsg 3 menyebabkan sel terpisah dan epidermis terlepas yang disebut sebagai akantolisis. Secara klinis akan tampak sebagai vesikel dan bula. ${ }^{9,10}$ Pad sebagian besar kasus PV (50-70\%), lesi di bagian oral dapat dominan mendahului lesi di kulit. ${ }^{7,8}$ Lesi di kulit dapat lokalisata maupun generalisata, tampak vesikel maupun bula berdinding kendur berukuran kurang dari 1 $\mathrm{cm}$ sampai beberapa $\mathrm{cm}$ yang biasanya terdapat di atas kulit yang normal. ${ }^{10}$ Bula mudah pecah sehingga menjadi erosi dan ulkus yang nyeri disertai tanda Nikolsky yang positif. ${ }^{11,12}$ Lesi oral biasanya diawali dengan vesikel maupun bula. Tanda lebih lanjut dapat berupa deskuamasi atau erosi pada gusi, sementara pada bibir lesi dapat ditutupi krusta hemoragik yang tebal. ${ }^{10}$ Pada kasus ini, pasien mengeluh muncul gelembung kecil di punggung sejak 1 bulan. Kemudian gelembung tersebut membesar, bertambah banyak dan menyebar ke seluruh tubuh. Gelembung tidak gatal, namun mudah pecah menjadi luka dan rasa nyeri, tapi tidak sampai mengganggu aktivitas pasien. Pasien juga mengeluhkan sariawan di rongga mulut sejak 2 bulan lalu, sehingga sulit makan dan minum. Lesi PV pada kasus ini menunjukkan gambaran yang tidak spesifik, karena keluhan telah berlangsung 1 bulan baru dibawa ke IGD RSUP Sanglah. Pasien tidak mendapatkan perawatan luka yang adekuat selama di rumah dan menjalani terapi tradisional, sehingga bahan-bahan yang digunakan tersebut kemungkinan juga menyebabkan dermatitis kontak iritan dan memperparah kondisi lesi pasien.

Pemeriksaan histopatologi menunjukkan bula suprabasal dengan akantolisis. Lapisan basal kehilangan jembatan intraseluler, namun masih tetap melekat di dermis, menghasilkan gambaran 'tombstone appearance'. Lesi PV fase awal menunjukkan spongiosis eosinofilik. Pada dermis ditemukan campuran infiltrat sel radang yang ringan dan terletak superfisial, biasanya terdapat eosinofil. ${ }^{1,10,12}$ Hasil pemeriksaan histopatologi dari jaringan kulit brachialis sinistra tampak dermis namun tidak tampak epidermis. Tampak sisa sel-sel di daerah adneksa. Sisa adneksa kulit tersebut menunjukkan akantolitik. Papila dermis disertai pemanjangan rete rigde, yang mengalami akantolisis. Tampak pula sebaran padat sel radang perivaskuler dan intertisial, terdiri atas leukosit polimorfonuklear, sel plasma, dan limfosit. Tidak tampak eosinofil pada sediaan ini. Gambaran morfologi mengarah pada gambaran PV.

Pada kasus ini penegakan diagnosis terutama berdasarkan klinis, sedangkan pemeriksaan histopatologi bersifat sebagai penunjang. Riwayat gelembung berair yang mudah pecah dan luka-luka di bibir sebelumnya mengarah pada gambaran klinis PV. Pada pemeriksaan histopatologi tidak tampak gambaran khas tombstone 
appearance, namun terdapat gambaran akantolitik dan celah suprabasal yang mengarah pada pemfigus vulgaris. Pemilihan lokasi biopsi yang representatif sulit dilakukan mengingat pasien datang dalam kondisi luka di seluruh tubuh yang telah diobati dengan obat herbal dan tidak terdapat bula baru. Pemeriksaan biopsi ulang dan imunofluoresensi belum dapat dilakukan karena terkendala biaya dan fasilitas.

Infeksi merupakan komplikasi yang sering terjadi pada pasien PV akibat kerusakan sawar epidermis pada lesi pemfigus, serta akibat penggunaan obat imunosupresif. Pada penelitian retrospektif terhadap 155 pasien PV didapatkan 33 orang mengalami infeksi saat masuk rumah sakit, 9 orang mengalami infeksi nosokomial, 37 orang menderita kandidiasis oral dan 15 orang mengalami herpes simpleks, sehingga total jumlah pasien PV yang mengalami infeksi sebanyak 94 orang. ${ }^{13,14}$ Infeksi yang terjadi, secara bermakna dipengaruhi oleh beberapa hal, antara lain keparahan penyakit, infeksi yang ditemukan pada saat masuk rumah sakit maupun pada saat menjalani perawatan, serta penyakit diabetes melitus. PV yang berat cenderung untuk mengalami infeksi Staphylococcus aureus merupakan patogen yang paling sering ditemukan dari pemeriksaan kultur bakteri. Staphylococcus aureus merupakan bakteri yang paling sering menyebabkan infeksi kulit pada pasien PV. Penelitian oleh Kanwar dan Dhar dari 10 kasus kematian akibat sepsis pada pasien PV, 4 di antaranya ditemukan Staphylococcus aureus sebagai patogen penyebab. ${ }^{13}$ Faktor risiko terjadi kolonisasi dan infeksi MRSA adalah usia tua, jenis kelamin laki-laki, riwayat rawat inap sebelumnya, lama rawat inap di rumah sakit, pasien dirawat di unit perawatan intensif, kondisi penyakit kronis, pengobatan antibiotika yang lama, terdapatnya luka dan ukuran luka, terpajan dengan pasien yang terinfeksi MRSA. Pada kasus ini, pasien menderita penyakit yang cukup lama dengan perawatan lama selama di rumah yang tidak adekuat, sehingga memudahkan terjadi infeksi.

Ulkus dekubitus adalah area jaringan nekrosis yang muncul ketika jaringan lunak tertekan antara tulang yang menonjol dan permukaan eksternal (tempat berbaring) dalam waktu yang lama. Jika pasien diam berbaring di tempat tidur di rumah sakit, tekanan yang sangat tinggi dapat terjadi hingga mencapai $150 \mathrm{mmHg}$. Pada suasana yang lembab, dari inkontinensia urin dan feses, penguapan dan drainase luka yang banyak, dapat menyebabkan maserasi kulit dan meningkatkan pembentukan ulkus. ${ }^{15}$ Faktor risiko terjadinya ulkus dekubitus pada pasien adalah usia tua, riwayat tirah baring yang lama, adanya kelembapan yang tinggi (karena urin, feses, eksudat dari luka serta cairan rempah-rempah) serta terdapat malnutrisi sedang. Pada pasien direncanakan debridement, namun ditunda karena kondisi pasien belum optimal dan dilakukan perawatan luka dekubitus dengan kompres serta tule antibiotika. Pasien mengalami perbaikan walaupun tanpa debridement. Prognosis pada pasien dubius karena perbaikan lesi yang signifikan, namun masih tetap dilakukan observasi.

\section{SIMPULAN}

Pemfigus vulgaris merupakan penyakit autoimun kronik yang menyebabkan pembentukan bula progresif dan erosi kronis. Pemfigus vulgaris seringkali disertai komplikasi infeksi karena erosi akibat pecahnya bula. Tatalaksana infeksi dan perawatan luka yang tepat dan lebih dini akan memberikan perbaikan dan menghindarkan pasien dari ancaman mortalitas atau morbiditas berkepanjangan. Lesi PV pada kasus ini memberikan gambaran yang tidak spesifik, karena setelah 1 bulan baru di bawa ke IGD RSUP Sanglah. Akan tetapi pada pemeriksaan histopatologi didapatkan sisa adneksa kulit terebut menunjukkan akantolitik dan kemungkinan terdapat bula suprabasal. Pada perawatan di rumah sakit selama 22 hari didapatkan perbaikan klinis.

\section{DAFTAR PUSTAKA}

1. Stanley JR. Pemphigus. Dalam: Wolff K, Goldsmith LA, Katz SI, Gilchrest BA, Paller AS, Leffel DJ, penyunting. Fitzpatrick's Dermatology In General Medicine. Edisi ke-8. New York: McGraw Hill;2012. h.1100-22.

2. Hasan S, Khan NI, Sherwani OA, Bhatt V, Srivastava H. Pemphigus vulgaris: An insight on conventional and emerging treatment modalities. Int Res J Pharm. 2013;4:812.

3. Karisetty B, Redy KN, Lahkar M. Prevalence of pemphigus vulgaris and pemphigus foliaceus in tertiary care hospital in India: an Update. Thep Pharma Innovation J. 2013:2;68-72.

4. Anonim. Buku Register Rawat Inap Rumah Sakit Umum Pusat Sanglah Denpasar:2014-2016.

5. Zeinab FA, Ahmad K, Rezvan M. The Prevalence of S.aureus skin and soft tissue infection in patients with pemphigus. Autoimune disesase. 2016. 1-5. http:// dx.doi.org/10.1155/2016/7529078.

6. Peraturan Direktur Utama RSUP Sanglah Denpasar Nomor: Hk.02.04/IV.C11-D23 tentang Panduan Pengelolaan Penempatan Pasien dengan Kuman Patogen Menular di RSUP Sanglah Denpasar.

7. Chmurova N, Svecova D. Pemphigus vulgaris: A 11-year review. Bratisl lek Listy. 2009;110:500-3

8. Ali FA, Ali JA. Pemphigus vulgaris and mucous membrane pemphigoid: update on etiopathogenesis, oral manifestations and management. J Clin Exp Dent. 2011;3: 246-50.

9. Weedon D. Pemphigus vulgaris, Pemphigus Vegetans. Dalam: Skin Pathology. Edisi ke-3. Philadelphia: Chruchill Livingstone; 2010. h.135-9.

10. Wonjnrowska F, Venning VA, Burge SM. Immunobullous diseases. Dalam: Burns T, Breathnach S. Cox N, Griffths C, penyunting. Rook's Textbook of Dermatology. Edisi ke-8. United Kingdom: Willey-Blackwell Ltd; 2010. h.40.1-40. 
11. Giurdanella F, Fania L, Gnarra M, Paola T, Rollo DD, Sauder DN, dkk. A possible role for CD8+ T lymphocytes in the cell-mediated pathogenesis of pemphigus vulgaris. Mediator of Inflamations. 2013:1-5.

12. Bradley M, Cullum N, Nelson EA, Petticrew M, Sheldon T, Torgerson D. Systematic reviews of wound care management: dressings and topical agents used in the healing of chronic wounds. Health Technology Assessment.1999:1-3

13. Nada M, Anne N, Raouf W, Hussein S. Clinical and histological characterization of oral pemphigus lesion in patient with skin diseases: A cross sectional study from Sudan. BMC Oral Health. 2013; 13:66.
14. Zeinab FA, Ahmad H, Rezvan M, Taereh S, Seyen GA. The prevalence of S.aureus skin and soft tissue infection in patient with pemphigus. Autoimmune Diseases. 2016:1-5.

15. Nafiseh Esmaili, Hossen M, Pedram N, Majid Boreiri, dkk. Pemphigus vulgaris and infections: a retrospective study on 155 patients. Autoimmune Diseases. 2013:1-5.

16. Jennifer G. Power, Lillian Odo, Tania J Philips. Decubitus (Pressure) Ulcers. Dalam: Wolff K, Goldsmith LA, Kazt Si, Gilcherest BA, Paller AS, Leffell DJ, penyunting. Dalam: Fitzpatrick's Dermatology in General Medicine. Edisi ke-8. New York: Mc Graw-Hill;2012. h.1121-9 